\title{
Knowledge and behavior of dentists in a dental school regarding toothbrush disinfection
}

\author{
Ilkay PEKER ${ }^{(a)}$ \\ Zuhre AKARSLAN(a) \\ Adil BASMAN ${ }^{(b)}$ \\ Nur HACIOSMANOGLU(a) \\ (a) Gazi University, Faculty of Dentistry, \\ Department of Dentomaxillofacial \\ Radiology, Ankara, Turkey. \\ (b)Gazi University, Faculty of Dentistry, \\ Department of Periodontology, Ankara, Turkey.
}

Declaration of Interests: The authors certify that they have no commercial or associative interest that represents a conflict of interest in connection with the manuscript.

Corresponding Author:

Ilkay Peker

E-mail: drilkaypeker@gmail.com

DOI: 10.1590/1807-3107BOR-2015.vol29.0048

Submitted: Jul 26, 2014

Accepted for publication: Dec 18, 2014

Last revision: Feb 06, 2015

\begin{abstract}
The aim of this study was to evaluate the knowledge and behavior of dentists regarding toothbrush disinfection. This study included 147 dentists (88 women and 59 men) who were actively employed at a dental school in Ankara, Turkey. Participants were asked to fill out a standard questionnaire, which contained questions regarding their demographics, brushing habits, toothbrush storage and disinfection habits, toothpaste use, knowledge about toothbrush disinfection, and whether they advised their patients about toothbrush storage. Descriptive statistics were calculated, and statistical analyses were performed with t-tests, chi-squared tests, and Fisher exact tests, where appropriate. Among the 147 surveyed dentists, $62.6 \%$ and $85.7 \%$ reported that they did not have any knowledge about toothbrush disinfection and did not disinfect their toothbrushes, respectively. However, approximately two thirds of surveyed dentists thought that toothbrush disinfection should be performed by everyone, including healthy individuals. Significant associations were found between knowledge about toothbrush disinfection and the professional title of dentists, how they stored their toothbrushes, and whether their toothbrushes were in contact with each other during storage $(p<0.05)$. A minority of dentists reported that they disinfected their toothbrushes.
\end{abstract}

Keywords: Dentists; Toothbrushing; Disinfection.

\section{Introduction}

Toothbrushes can become contaminated in the intra- or extraoral environment, thereafter serving as reservoirs for several microorganisms. ${ }^{1,2}$ After usage, toothbrushes are heavily contaminated with various pathogenic bacteria and viruses, ${ }^{2,3,4,5}$ which can maintain their viability on the toothbrush for up to a week. ${ }^{6}$ Toothbrushes that are contaminated with sufficient amounts of herpes simplex virus 1 could cause infection, ${ }^{4}$ and contaminated toothbrushes may play important roles in many oral and systemic diseases, including septicemia and gastrointestinal, cardiovascular, respiratory, and renal problems. ${ }^{7}$

In recent years, the issue of toothbrush disinfection has become increasingly important. Toothbrush disinfection has been recommended for children, elderly people, vulnerable populations in a hospital setting (e.g., critically ill adults), and high-risk patients, such as individuals who are immunosuppressed or undergoing organ transplantation or chemotherapy.,3 
The American Dental Association (ADA) ${ }^{8}$ recommends that high-risk patients soak their used toothbrushes in an antimicrobial mouth rinse for disinfection. However, there are no standard disinfection recommendations or procedures for healthy individuals. Studies have suggested different methods for disinfecting toothbrushes to prevent disease, ${ }^{9,10}$ including the use of chemical agents, ultraviolet sanitizers, microwave irradiation, and dishwashing. $2,5,7,9,10,11,12$

Although the disinfection methods of toothbrushes ${ }^{1,29,12}$ have been investigated in several studies, to the best of our knowledge, no published study has reported the knowledge and behavior of dentists about toothbrush disinfection. Therefore, this study aimed to evaluate these aspects among dentists employed at a dental school in Turkey.

\section{Methodology}

This study was conducted among dentists who were employed at the Gazi University Faculty of Dentistry in Ankara, Turkey. This study was approved by the Ethics Board of the Institutional Ethics Committee of Ankara University Faculty of Dentistry (No: 18/4, 12.03.2014, Ankara, Turkey). All participants provided written informed consent before enrollment in the study. A standard questionnaire was prepared and distributed to dentists (Table 1), which contained 17 items in three parts: demographics (6 items), personal toothbrush/toothpaste use and patient recommendations (7 items), and toothbrush disinfection (4 items). Each dentist filled out the questionnaire by him/herself. Of the 150 questionnaires that were distributed to dentists, three forms were filled out incompletely and were excluded from the study, resulting in 147 evaluated forms. Data were statistically analyzed by using SPSS-15.0 version (SPSS Inc., Chicago, USA) for Windows with descriptive statistics, t-tests, Fisher exact tests, and chi-squared tests, as appropriate. Differences with a p-value of less than 0.05 were considered statistically significant.

\section{Results}

The questionnaire results are summarized in Table 2. A total of 147 dentists, including 88 women (59.9\%) and 59 men (40.1\%), filled out the questionnaire in full. Participants ranged in age from 23 to 65 years (mean age \pm standard deviation: $33.82 \pm 0.03$ years).
Table 1. Questionnaire used in the study.

Demographics
1. Age
2. Biological sex
3. When did you graduate from the dental school?
a) $0-5$ years ago
b) $6-10$ years ago
c) $11+$ years ago

4. Which dental school did you graduate from?
a) Gazi University (Ankara, Turkey)
b) Ankara (Ankara, Turkey)
c) Hacettepe (Ankara, Turkey)y
d) University in another city in Turkey
e) University in another country

5. What is your specialty?

a) Oral and Maxillofacial Surgery

b) Restorative Dentistry

c) Endodontics

d) Periodontology

e) Dentomaxillofacial Radiology

f) Prosthetic dentistry

g) Oral Pathology

h) Orthodontics

i) Pediatric Dentistry

6. What is your title?
a) Student in a Specialty program
b) Specialist
c) Assistant Professor
d) Associate Professor
e) Professor

Personal toothbrush/toothpaste habits and patient recommendations

7. How often do you brush your teeth?
a) Once a day
b) Twice or more a day

8. How often do you change your toothbrush?
a) Once in a month
b) Bimonthly
c) Once every 3 months
d) After 3 months or more

9. Where do you store your toothbrush?

a) In the bathroom, in open contact with the environment

b) In the bathroom, in a closed cabinet

10. How do you store your toothbrush?

a) In a toothbrush holder shared with other family members

b) Separately from the toothbrushes of other family members

11. In your opinion, is the contact between toothbrushes an important issue?

a) No

Continue 


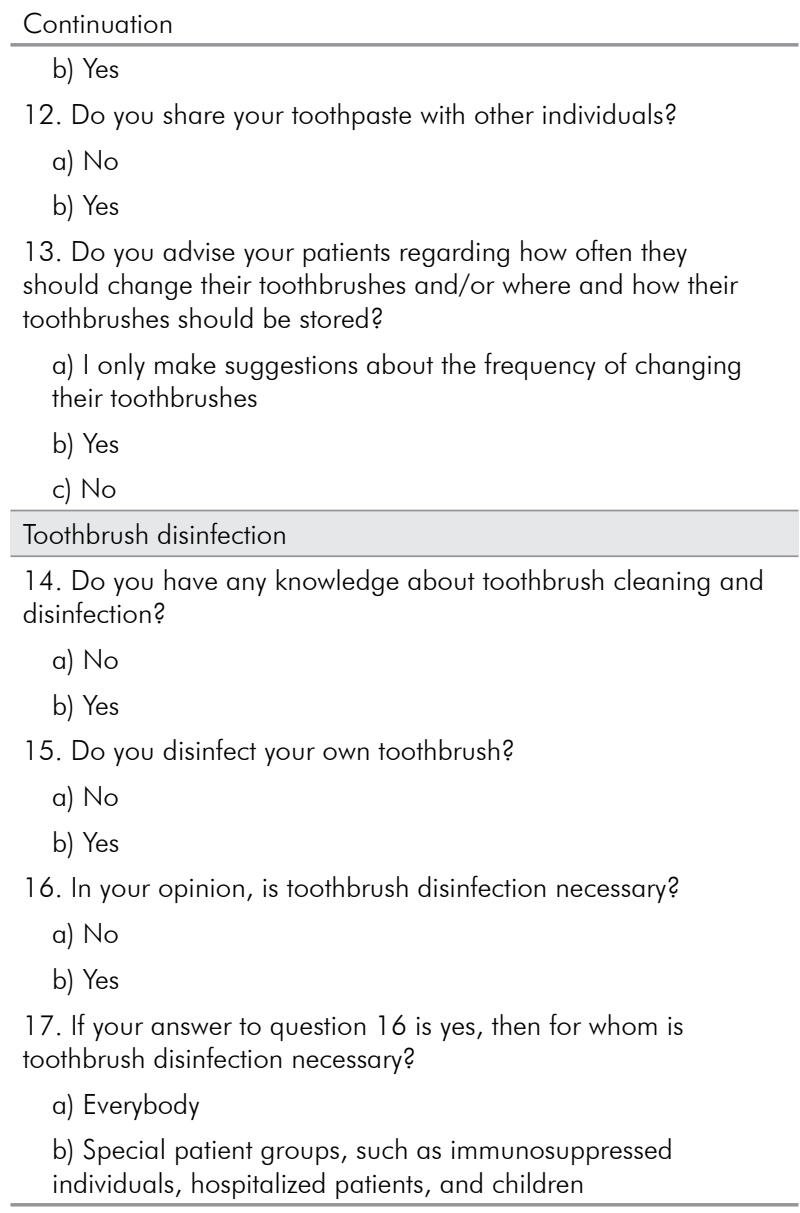

No significant difference in mean age was found between men and women ( $p>0.05)$. However, there were significantly more female than male dentists in the study $(\mathrm{p}<0.05)$. Most dentists had graduated from dental school 0 to 5 years ago $(n=71,48.3 \%$ ), with the largest percentage of participants graduating from Gazi University ( $n=57,38.8 \%$ ). Among the sample, the largest percentages of participants were employed in the Periodontology Department $(n=34,23.1 \%)$ and had specialized during their dental training $(n=88,59.9 \%)$. Men and women differed significantly in where they attended dental school ( $\mathrm{p}<0.05)$.

Most dentists reported that they brushed their teeth at least twice a day $(n=128,87.1 \%)$, stored their toothbrushes in a closed cabinet in the bathroom ( $\mathrm{n}=78,53.1 \%$ ) separately from other toothbrushes $(\mathrm{n}=78,53.1 \%)$, thought that contact between toothbrushes was important $(n=124,84.3 \%)$, and shared their toothpaste with other individuals ( $\mathrm{n}=89,60.5 \%)$. Most dentists advised their patients about the frequency of changing and storage conditions for their toothbrushes ( $n=105,71.4 \%$ ). Most female dentists thought that contact between toothbrushes was important issue ( $\mathrm{n}=81,92 \%$ ), with significant differences between men and women for this question $(p<0.05)$.

Table 2. Descriptive statistical results of the questionnaire, according to biological sex.

\begin{tabular}{|c|c|c|c|c|}
\hline \multirow{2}{*}{ Questions } & & \multicolumn{2}{|c|}{ Biological sex } & \multirow{3}{*}{$\mathrm{p}$-value } \\
\hline & & \multirow{2}{*}{$\begin{array}{c}\text { Female } \\
\mathrm{N}(\%)\end{array}$} & \multirow{2}{*}{$\begin{array}{l}\text { Male } \\
\text { N (\%) }\end{array}$} & \\
\hline \multirow{2}{*}{\multicolumn{5}{|c|}{ Demographics }} \\
\hline & & & & \\
\hline 1. Age & $\begin{array}{l}\text { Mean age } \pm \text { standard deviation; } \\
33.8 \pm 0.03\end{array}$ & $33.1 \pm 8.8$ & $34.9 \pm 11.6$ & $0.297^{a}$ \\
\hline 2. Biological Sex & & $88(59.9)$ & $59(40.1)$ & $0.017^{\mathrm{b}, *}$ \\
\hline \multirow{3}{*}{$\begin{array}{l}\text { 3. When did you graduate from the dental } \\
\text { school? }\end{array}$} & a) $0-5$ years ago & $42(47.7)$ & $29(49.2)$ & $0.880^{\mathrm{b}}$ \\
\hline & b) $6-10$ years ago & $13(14.8)$ & 7 (1 1.9) & \\
\hline & c) $11+$ years ago & $33(37.5)$ & $23(39.0)$ & \\
\hline \multirow{5}{*}{$\begin{array}{l}\text { 4. Which dental school did you graduate } \\
\text { from? }\end{array}$} & a) Gazi University (Ankara, Turkey) & $34(38.6)$ & $23(39.0)$ & $0.043^{\mathrm{b}, *}$ \\
\hline & b) Ankara(Ankara, Turkey) & $26(29.5)$ & $15(25.4)$ & \\
\hline & c) Hacettepe (Ankara, Turkey) & $15(17.0)$ & 7 (1 1.9) & \\
\hline & d) University in another city in Turkey & $13(14.8)$ & $8(13.6)$ & \\
\hline & e) University in another country & $0(0.0)$ & $6(10.2)$ & \\
\hline \multirow[t]{3}{*}{ 5. What is your specialty? } & a) Oral and Maxillofacial Surgery & $8(9.1)$ & $20(33.9)$ & $\dagger$ \\
\hline & b) Restorative Dentistry & $7(8.0)$ & $4(6.8)$ & \\
\hline & c) Endodontics & $6(6.8)$ & $3(5.1)$ & \\
\hline
\end{tabular}


Continuation

\begin{tabular}{|c|c|c|c|c|}
\hline & d) Periodontology & $23(26.1)$ & $11(18.6)$ & \\
\hline \multirow{10}{*}{ 6. What is your title? } & e) Dentomaxillofacial Radiology & $7(8.0)$ & $3(5.1)$ & \multirow{10}{*}{$0.552^{b}$} \\
\hline & f) Prosthetic dentistry & $20(22.7)$ & $9(15.3)$ & \\
\hline & g) Oral Pathology & $3(3.4)$ & $3(5.1)$ & \\
\hline & h) Orthodontics & $14(15.9)$ & $5(8.5)$ & \\
\hline & i) Pediatric Dentistry & $0(0.0)$ & $1(1.7)$ & \\
\hline & a) Student in a Specialty program & $52(59.1)$ & $36(61.0)$ & \\
\hline & b) Specialist & $11(12.5)$ & $3(5.1)$ & \\
\hline & c) Assistant Professor & $2(2.3)$ & $3(5.1)$ & \\
\hline & d) Associate Professor & $9(10.2)$ & $6(10.2)$ & \\
\hline & e) Professor & $14(15.9)$ & $11(18.6)$ & \\
\hline \multicolumn{5}{|c|}{ Personal toothbrush/toothpaste habits and patient recommendations } \\
\hline \multirow[t]{2}{*}{ 7. How often do you brush your teeth? } & a) Once a day & $9(10.2)$ & $10(16.9)$ & \multirow[t]{2}{*}{$0.234^{b}$} \\
\hline & b) Twice or more a day & $79(89.8)$ & $49(83.1)$ & \\
\hline \multirow{4}{*}{$\begin{array}{l}\text { 8. How often do you change your } \\
\text { toothbrush? }\end{array}$} & a) Once in a month & $13(14.8)$ & $9(15.3)$ & \multirow[t]{4}{*}{$0.501^{\mathrm{b}}$} \\
\hline & b) Bimonthly & $26(29.5)$ & $15(25.4)$ & \\
\hline & c) Once every 3 months & $39(44.3)$ & $23(39.0)$ & \\
\hline & d) After 3 months or more & $10(11.4)$ & $12(20.3)$ & \\
\hline \multirow[t]{2}{*}{ 9. Where do you store your toothbrush? } & $\begin{array}{l}\text { a) In the bathroom, in open contact } \\
\text { with the environment }\end{array}$ & $40(45.5)$ & $29(49.2)$ & \multirow[t]{2}{*}{$0.746^{b}$} \\
\hline & b) In the bathroom, in a closed cabinet & $48(54.5)$ & $30(50.8)$ & \\
\hline \multirow[t]{2}{*}{ 10. How do you store your toothbrush? } & $\begin{array}{l}\text { a) In a toothbrush holder shared with } \\
\text { other family members }\end{array}$ & $40(45.5)$ & $29(49.2)$ & \multirow[t]{2}{*}{$0.746^{\mathrm{b}}$} \\
\hline & $\begin{array}{l}\text { b) Separately from the toothbrushes of } \\
\text { other family members }\end{array}$ & $48(54.5)$ & $30(50.8)$ & \\
\hline \multirow{2}{*}{$\begin{array}{l}\text { 11. In your opinion, is the contact between } \\
\text { toothbrushes an important issue? }\end{array}$} & a) No & $7(8.0)$ & $16(27.1)$ & \multirow[t]{2}{*}{$0,002^{b, *}$} \\
\hline & b) Yes & $81(92.0)$ & $43(72.9)$ & \\
\hline \multirow{2}{*}{$\begin{array}{l}\text { 12. Do you share your toothpaste with } \\
\text { other individuals? }\end{array}$} & a) No & $37(42.0)$ & $21(35.6)$ & \multirow[t]{2}{*}{$0.433^{b}$} \\
\hline & b) Yes & $51(58.0)$ & $38(64.4)$ & \\
\hline \multirow{3}{*}{$\begin{array}{l}\text { 13. Do you advise your patients regarding } \\
\text { how often they should change their } \\
\text { toothbrushes, and how their toothbrushes } \\
\text { should be stored? }\end{array}$} & $\begin{array}{l}\text { a) I only make suggestions about } \\
\text { the frequency of changing their } \\
\text { toothbrushes }\end{array}$ & $61(69.3)$ & $44(74.6)$ & \multirow[t]{3}{*}{$0.720^{b}$} \\
\hline & b) Yes & $7(8.0)$ & $3(5.1)$ & \\
\hline & c) No & $20(22.7)$ & $12(20.3)$ & \\
\hline \multicolumn{5}{|c|}{ Toothbrush disinfection } \\
\hline \multirow{2}{*}{$\begin{array}{l}\text { 14. Do you have any knowledge about } \\
\text { toothbrush cleaning and disinfection? }\end{array}$} & a) No & $53(60.2)$ & $39(66.1)$ & \multirow[t]{2}{*}{$0.471^{\mathrm{b}}$} \\
\hline & b) Yes & $35(39.8)$ & $20(33.9)$ & \\
\hline \multirow[t]{2}{*}{ 15. Do you disinfect your own toothbrush? } & a) No & $76(86.4)$ & $50(84.7)$ & \multirow[t]{2}{*}{$0.783^{b}$} \\
\hline & b) Yes & $12(13.6)$ & $9(15.3)$ & \\
\hline \multirow{2}{*}{$\begin{array}{l}\text { 16. In your opinion, is toothbrush } \\
\text { disinfection necessary? }\end{array}$} & a) No & $24(27.3)$ & $26(44.1)$ & \multirow[t]{2}{*}{$0.005^{b, *}$} \\
\hline & b) Yes & $64(72.7)$ & $33(55.9)$ & \\
\hline \multirow{2}{*}{$\begin{array}{l}\text { 17. If your answer to question } 16 \text { is yes, } \\
\text { then for whom is toothbrush disinfection } \\
\text { necessary? }\end{array}$} & a) Everybody & $42(65.6)$ & $21(63.6)$ & \multirow[t]{2}{*}{$0.709^{b}$} \\
\hline & $\begin{array}{l}\text { b) Special patient groups, such as } \\
\text { immunosuppressed individuals, } \\
\text { hospitalized patients and children }\end{array}$ & $22(34.4)$ & $12(36.4)$ & \\
\hline
\end{tabular}

Statistical analysis result according to t-test.

bStatistical analysis result according to Chi-squared test.

*Difference is statistically significant, $p<0.05$.

${ }^{+}$Chi-square test is not applicable. 
Dentists who answered "yes" to the question "Do you have any knowledge about toothbrush cleaning and disinfection?" were considered to have knowledge about toothbrush disinfection. Surveyed dentists reported a lack of knowledge about the issue of toothbrush disinfection ( $\mathrm{n}=92,62.6 \%$ ), and most did not disinfect their own toothbrushes $(n=126,85.7 \%)$. However, most dentists thought that toothbrush disinfection was necessary $(n=97,66 \%)$ for everyone $(n=63,65 \%)$. A minority of dentists indicated that they disinfected their own toothbrushes ( $\mathrm{n}=21,14.3 \%)$, and female dentists more often gave a positive response to this question compared to male dentists $(\mathrm{p}<0.05)$.
Knowledge about toothbrush disinfection was significantly associated with a greater level of education and with toothbrush storage in a closed cabinet in the bathroom $(\mathrm{p}<0.05)$. A significant association was found between dentists who disinfected their toothbrushes and dentists who were aware of the importance of contact between toothbrushes $(p<0.05)$. Details of these results are given in Table 3.

\section{Discussion}

This study assessed the knowledge and behavior of dentists about toothbrush disinfection, and sought to identify any associations between the knowledge of the dentists and their dental school, specialty area, title,

Table 3. Statistical analysis of the association of knowledge about toothbrush disinfection with other variables.

\begin{tabular}{|c|c|c|c|c|}
\hline \multirow{2}{*}{ Questions } & & \multicolumn{3}{|c|}{ Statistical analysis } \\
\hline & & $n(\%)^{c}$ & Chi-square & p-value \\
\hline \multirow{5}{*}{$\begin{array}{l}\text { 4. Which dental school did you } \\
\text { graduate from? }\end{array}$} & a) Gazi University (Ankara, Turkey) & $25(43.9)$ & 3.383 & $0.496^{b}$ \\
\hline & b) Ankara (Ankara, Turkey) & $15(36.6)$ & & \\
\hline & c) Hacettepe (Ankara, Turkey) & $7(31.8)$ & & \\
\hline & d) Universities in other city of Turkey & $5(23.8)$ & & \\
\hline & e) Universities in other country & $3(50.0)$ & & \\
\hline \multirow[t]{9}{*}{ 5. What is your specialty? } & a) Oral and Maxillofacial Surgery & $8(28.6)$ & 8.732 & $0.365^{b}$ \\
\hline & b) Restorative Dentistry & $5(45.5)$ & & \\
\hline & c) Endodontics & $3(33.3)$ & & \\
\hline & d) Periodontology & $13(38.2)$ & & \\
\hline & e) Dentomaxillofacial Radiology & $7(70.0)$ & & \\
\hline & f) Prosthetic dentistry & $10(34.5)$ & & \\
\hline & g) Oral Pathology & $1(16.7)$ & & \\
\hline & h) Orthodontics & $7(36.8)$ & & \\
\hline & i) Pediatric Dentistry & $1(100.0)$ & & \\
\hline \multirow[t]{5}{*}{ 6. What is your title? } & a) Student in a Specialty program & $25(28.4)$ & 14.834 & $0.005^{\mathrm{b}, *}$ \\
\hline & b) Specialist & $3(21.4)$ & & \\
\hline & c) Assistant Professor & $3(60.0)$ & & \\
\hline & d) Associate Professor & $10(66.7)$ & & \\
\hline & e) Professor & $14(56.0)$ & & \\
\hline \multirow{2}{*}{$\begin{array}{l}\text { 9. Where do you store your } \\
\text { toothbrush? }\end{array}$} & a) In the bathroom, in open contact with the environment & $40(39.2)$ & 14.613 & $0.006^{\mathrm{b}, *}$ \\
\hline & b) In the bathroom, in a closed cabinet & $19(42.2)$ & & \\
\hline \multirow{2}{*}{$\begin{array}{l}\text { 11. In your opinion is the } \\
\text { contact between toothbrushes } \\
\text { an important issue? }\end{array}$} & a) No & $4(17.4)$ & 4.669 & $0.031^{\mathrm{b}, *}$ \\
\hline & b) Yes & $51(41.1)$ & & \\
\hline \multirow{2}{*}{$\begin{array}{l}\text { 15. Do you disinfect your own } \\
\text { toothbrush? }\end{array}$} & a) No & $34(27.0)$ & - & $0.000^{a, *}$ \\
\hline & b) Yes & $21(100.0)$ & & \\
\hline
\end{tabular}

aStatistical analysis result according to Fisher exact test.

bStatistical analysis result according to Chi-squared test.

"Number and percentage of participants who answered "yes" to the question "Do you have any knowledge about toothbrush cleaning and disinfection?"

*Difference is statistically significant, $p<0.05$ 
and toothbrush storage conditions. Approximately $60 \%$ and $80 \%$ of participants did not have any knowledge about toothbrush disinfection and did not disinfect their own toothbrushes, respectively. However, about $65 \%$ of participants indicated that toothbrush disinfection was required of all individuals. Fifteen percent of dentists declared that they disinfected their own toothbrushes. Statistically significant differences were found between male and female dentists in terms of having knowledge about toothbrush disinfection, with significantly more female dentists giving a positive response to the question of whether toothbrush disinfection was needed. As there is no similar study in the literature, we could not compare our results with previous studies.

This study was conducted at a university in Ankara, Turkey. Dentists who participated in the study were graduates of various universities of Turkey (located in Ankara and other major urban areas) and universities in other countries. Dentists were from different specialty areas and had various employment experiences, ranging from approximately 0 to 11 years in all academic positions, with titles including student in a specialty program, specialist, assistant professor, associate professor, and professor.

Among the dentists who reported having knowledge about toothbrush disinfection, a greater number had higher academic degrees (associate professors, assistant professors and professors). A significant association was found between the dentist's title and knowledge about toothbrush disinfection. It may be that dentists with more educational background have a greater awareness of toothbrush disinfection, or that they pay special attention to the issue or to research related to toothbrush disinfection.

A dentist's tasks include motivating and educating their patients about oral health behavior and integrating preventive procedures. ${ }^{13}$ Dentists are expected to be role models for their patients and to have adequate knowledge about essential oral hygiene practices and behavior. ${ }^{13}$ For optimal oral health, tooth brushing should be carried out more than once a day. Several studies have investigated oral health behavior and attitudes among dentists in different countries, ${ }^{13,14,15,16,17}$ reporting that most dentists brush their teeth at least twice a day. However, the prevalence of dentists who brush their teeth at least twice a day varies in a wide range in different populations (from $~ 55 \%$ to $83 \%$ ). ${ }^{13,14,15,16,17}$ In this study, approximately $87 \%$ of dentists brushed their teeth twice a day or more. This relatively high percentage compared to previous reports might be because the study was carried out at a university, and all of the surveyed dentists had at least a postgraduate education. The oral health behavior of female dentists has been reported to be generally better than that of male dentists, and most female dentists reportedly brush their teeth at least twice daily. ${ }^{13,17}$ Consistent with previous studies, a greater number of female than male dentists brushed their at least teeth twice daily. This finding may be explained on the basis that women usually care more about their body and appearance than men.

The $\mathrm{ADA}^{8}$ recommends that toothbrushes be replaced every 3 to 4 months, or sooner if the bristles appear worn or splayed. However, this recommendation is based on the loss of mechanical efficiency, not on bacterial contamination of the toothbrush. ${ }^{8}$ In this study, most participants declared that toothbrushes should be replaced once every 3 months, consistent with the recommendations of the ADA. ${ }^{8}$ Moreover, $72 \%$ of dentists advised their patients about the frequency of changing their toothbrushes.

Several factors, such as storage circumstances, toothbrush location, reintroduction of microorganisms in the oral cavity, and cross-infection, affect toothbrush contamination. ${ }^{2}$ Recommendations for toothbrush storage include using cup hooks to hang the brushes, cutting a hole in the top of a carton box to store the brush, using closed and/or vented containers, and using a brush box. ${ }^{2}$ Previous studies have reported that the number of bacteria is higher in toothbrushes that are stored in closed containers compared to those left open to air. The use of a toothbrush cap has also been reported to increase bacterial survival on toothbrushes. ${ }^{2,5,18}$ Nascimento et al. ${ }^{19}$ investigated the effectiveness of three antimicrobial mouth rinses for toothbrush disinfection under in vivo conditions. The participants of that study stored their toothbrushes in closed containers to avoid external contamination. In general, contamination can arise when toothbrushes and toothpastes are shared, or when toothbrushes are 
stored with the toothbrushes of other individuals.,20 In this study, the surveyed dentists mostly stored their toothbrushes in closed places in a toothbrush holder shared with other individuals, and they shared their toothpaste with other individuals. Compared to male dentists, significantly more female dentists indicated that they thought contact between toothbrushes was an important issue.

Currently, there are no standard recommendations on toothbrush disinfection for healthy individuals, although toothbrushes are contaminated with microorganisms ${ }^{21}$ soon after their initial use, and this contamination increases with repeated use. ${ }^{1,2,15,22}$ On the other hand, it is not clear whether this contamination is significant or not. ${ }^{23}$ Approximately $40 \%$ of the dentists surveyed in this study thought that toothbrush disinfection should be performed by everyone, including healthy individuals. Only $20 \%$ of dentists thought that toothbrush disinfection was necessary only for special patient groups, such as immunocompromised individuals, hospitalized patients, and children.

Despite the ADA's recommendation that highrisk patients disinfect their used toothbrushes, ${ }^{8}$ this suggestion is not always followed in the hospital setting. Nurses commonly perform oral hygiene procedures for hospitalized patients, whose toothbrushes are stored under various conditions (e.g., in the bath basin

\section{References}

1. Devine DA, Percival RS, Wood DJ, Tuthill TJ, Kite P, Killington RA, et al. Inhibition of biofilms associated with dentures and toothbrushes by tetrasodium EDTA. J Appl Microbiol. 2007 Dec;103(6):2516-24.

2. Ankola AV, Hebbal M, Eshwar S. How clean is the toothbrush that cleans your tooth?. Int J Dent Hyg. 2009 Nov;7(4):237-40.

3. Frazelle MR, Munro CL. Toothbrush contamination: a review of the literature. Nurs Res Pract. 2012;2012:420630. DOI: 10.1155/2012/420630. Epub 2012 Jan 24.

4. Grewal N, Swaranjit K. A study of toothbrush contamination at different time intervals and comparative effectiveness of various disinfecting solutions in reducing toothbrush contamination. J Indian Soc Pedod Prev Dent. 1996 Mar;14(1):10-3.

5. Sconyers JR, Crawford JJ, Moriarty JD. Relationship of bacteremia to toothbrushing in patients with periodontitis. J Am Dent Assoc. 1973 Sep;87(3):616-22. with other bathing/personal supplies and linens, in a paper towel or plastic wrapper, on the bedside table, next to the sink, in an oral rinse cup at the bedside, etc.). ${ }^{3}$ Detailed standards and nursing guidelines about toothbrush contamination are needed, to decrease the risk of infection. ${ }^{3}$

\section{Conclusion}

Most surveyed dentists did not have any knowledge about toothbrush disinfection. Some dentists had this knowledge but did not perform toothbrush disinfection themselves. A minority of dentists did disinfect their toothbrushes. More awareness is needed about this issue for the clinical adoption of toothbrush disinfection among individuals. Further studies with participants working at different universities and/or private clinics and in various countries are required to profile a larger area.

\section{Acknowledgment}

The authors would like to thank to Dr. Tülin Otbiçer (Specialist in Measurement of Evaluation in Education, Ankara, Turkey) for data analysis and Kate Edmondson (Editing service: Write Science Right) for the language revision of the manuscript. The authors declare no potential conflict of interest with respect to the authorship and/or publication of this article.

6. Spolidorio DM, Goto E, Negrini TC, Spolidorio LC. Viability of Streptococcus mutans on transparent and opaque toothbrushes. J Dent Hyg. 2003 Spring;77(2):114-7.

7. Nascimento AP, Watanabe E, Ito IY. Toothbrush contamination by Candida spp. and efficacy of mouthrinse spray for their disinfection. Mycopathologia. 2010 Feb;169(2):133-8.

8. American Dental Association - ADA. [Internet]. Positions and Statements. ADA statement on toothbrush care cleaning, storage, and replacement Council on Scientific Affairs; 2005 Nov [cited 2011 Apr 21]. Available from: http://www.ada.org/1887aspx.

9. Komiyama EY, Back-Brito GN, Balducci I, Koga-Ito CY. Evaluation of alternative methods for the disinfection of toothbrushes. Braz Oral Res. 2010 Jan-Mar;24(1):28-33.

10. Pedrazzi V, Sato S, Mattos MGC, Lara EH, Panzeri H. Tongue-cleaning methods: a comparative clinical trial employing a toothbrush and a tongue scraper. J Periodontol. 2004 Jul;75(7):1009-12. 
11. Taji SS, Rogers AH. ADRF Trebitsch Scholarship. The microbial contamination of toothbrushes. A pilot study. Aust Dent J. 1998 Apr;43(2):128-30.

12. Belanger-Giguere K, Giguere S, Belanger M. Disinfection of toothbrushes contaminated with Streptococcus mutans. Am J Dent. 2011 Jun;24(3):155-8.

13. Wagle M, Trovik TA, Basnet P, Acharya G. Do dentists have better oral health compared to general population: a study on oral health status and oral health behavior in Kathmandu, Nepal. BMC Oral Health. 2014 Mar:22;14:23.

14. Singh MS, Tuli AK. A comparative evaluation of oral hygiene practices, oral health status, and behavior between graduate and post-graduate dentists of North India: An epidemiological survey. J Int Soc Prev Community Dent. 2013 Jan-Jun;3(1):19-24.

15. Gopinath V. Oral hygiene practices and habits among dental professionals in Chennai. Indian J Dent Res. 2010 Apr-Jun;21(2):195-200.

16. Tseveenjav B, Vehkalahti M, Murtomaa H. Oral health and its determinants among Mongolian dentists. Acta Odontol Scand. 2004 Feb;62(1):1-6.
17. Peker I, Alkurt MT. Oral health attitudes and behavior among a group of Turkish dental students. Eur J Dent. 2009 Jan;3(1):24-31.

18. Dayoub MB, Rusilko D, Gross A. Microbial contamination of toothbrushes. J Dent Res. 1977 Jun;56(6):706.

19. Nascimento CD, Sorgini MB, Pita MS, Fernandes FH, Calefi PL, Watanabe E, et al. Effectiveness of three antimicrobial mouthrinses on the disinfection of toothbrushes stored in closed containers: a randomized clinical investigation by DNA Checkerboard and Culture. Gerodontology. 2014 Sep;31(3):227.36. DOI: 10.1111/ger.12035.

20. Svanberg M. Contamination of toothpaste and toothbrush by Streptococcus mutans. Scand J Dent Res. 1978 Sep;86(5):412-4.

21. Efstratiou M, Papaioannou W, Nakou M, Ktenas E, Vrotsos IA, Panis V. Contamination of a toothbrush with antibacterial properties by oral microorganisms. J Dent. 2007 Apr;35(4):331-7.

22. Karibasappa GN, Nagesh L, Sujatha BK. Assessment of microbial contamination of toothbrush head: An in vitro study. Indian J Dent Res. 2011 Jan-Feb;22(1):2-5.

23. Richards D. How clean is your toothbrush?. Evid Based Dent. 2012;13(4):111. DOI: 10.1038/sj.ebd.6400895. 